\title{
Review of Serengeti III: human impacts on ecosystem dynamics edited by ARE Sinclair, Craig Packer, Simon Mduma and John M Fryxell
}

Katherine Homewood

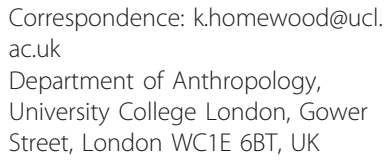

\section{Book details}

Sinclair ARE, Packer Craig, Mduma Simon and Fryxell John M: Serengeti III: Human Impacts on Ecosystem Dynamics Chicago: Chicago University Press; 2008:522. 50 halftones, 65 line drawings, 37 tables, ISBN-13: 978-0-226-76033-9 CLOTH ISBN-13: 978-0-226-76034-6 PAPER

The Serengeti is arguably the best-studied ecosystem in sub-Saharan Africa, at least from an ecological viewpoint. This volume represents the third of Sinclair and co-workers' long term project of fostering, coordinating and carrying out work in the Serengeti and is co-edited with other longstanding researchers of this endlessly fascinating system. The book brings much new material and novel analyses, particularly modelling expertise, to build on existing work. It also heralds a change of emphasis. From the 1979 Serengeti I: dynamics of an ecosystem and the 1995 Serengeti II: dynamics, management and conservation, we now have Serengeti III: human impacts on ecosystem dynamics. This is in recognition that in order to understand the changes Serengeti has seen and its different possible futures, it is necessary to move on from the biophysical 'hard' science to the difficult science of social, economic and political drivers. This is an exciting and groundbreaking move.

The book is organised into 16 chapters mostly with multi-authors. The brief introduction sets out the work's intellectual goals, moving from modelling individual behaviour to modelling the whole ecosystem, capturing emergent properties and predicting the behaviour of complex systems, in a bid to contribute to management of the Serengeti and other ecosystems. The introduction invokes links to poverty alleviation and the imperative of engaging protected area-adjacent communities. Chapter 2 recapitulates the biophysical characteristics of the system and the broad-brush changes witnessed over the last century of observation. Chapter 3 presents a fascinating synthesis of palaeoecology of the last four to five million years. It establishes convincingly (and contrary to earlier thinking) that the Serengeti we see today, with its short grass plains, wooded grasslands and spectacular migrations, is a recent phenomenon that emerged with the formation over the last 100,000 years of Lake Victoria, the volcanic highlands and the nutrient-rich volcanic ash plains in their rainshadow. Chapter 4 deals with history and prehistory of the people's use of the Serengeti, with the authors drawing 
primarily on two established Africanist sources: Ehret's (2002) linguistics-based synthesis of the history of different cultural and food-producing traditions across Africa and (Iliffe's 1979, 1987) authoritative histories of the African poor and of Tanzania in particular. Chapter 4 also looks at the spatial distribution of Serengeti grazers, arriving at perhaps unsurprising conclusions that (a) distribution and movement of species relate to soil fertility and rainfall and (b) while domestic livestock distribution diverges strongly from that of wild grazers, this is primarily due to its exclusion from protected areas.

Chapter 5 looks in depth at the sources and drivers of heterogeneity in the Serengeti: how can grassland plains support such astonishing biodiversity? Starting from a formal categorisation of types and levels of heterogeneity, the chapter goes on to give climate, topography, soils, fire, termites and effects of different plant species and formations on soils their due. Intriguingly, no research exists on historical pastoralist land use and livestock management as agents of heterogeneity creating hotspots of nutrient fertility in the Serengeti landscape, despite this having been demonstrated in adjacent systems. Chapter 6 reports on modelling exercises with a view to scope the future effects of climate change. Global climatic model predictions are at odds with empirical local observations, with temperature and rainfall showing distinct local patterns which suggest that wet season rainfall variance will decline and that there will be longer runs of dry or wet years. Together with rising $\mathrm{CO}_{2}$, these changes are predicted to shift the balance between $\mathrm{C}_{3}$ and $\mathrm{C}_{4}$ plant species. $\mathrm{C}_{3}$ and $\mathrm{C}_{4}$ refer to two groups of plants with different metabolic pathways for carbon fixation in photosynthesis. The two groups respond differently to increasing $\mathrm{CO}_{2}$, with $\mathrm{C}_{3}$ production increasing while $\mathrm{C}_{4}$ plants down-regulate photosynthesis, leading to greater water use efficiency but lower production overall. The upshot could be a reduced number of herbivores, an increase in dry season standing grass and litter-driving hot fires, a decline in production balanced by an increase in nutrient concentration of forage and a possible expansion of the short grass association component of the ecosystem. The predicted lower incidence of extremely high rainfall events could mean fewer opportunities for tree species to become established and a decline in plant diversity. This exploratory exercise is beautifully explained. At the same time, it is so dependent on poorly known interactions (additive? interactive? feedback effects?) that possible outcomes can range from the unsurprising to the completely counterintuitive. Broadly speaking, lower rainfall translates into less primary production and lower biodiversity, and these effects reverberate through the large mammal community, but not necessarily in predictable ways. Predictions as to a possible decline in livestock numbers around the Serengeti, as a result of postulated increased risks attached to banking wealth in livestock, seem to be particularly open to debate, as do the predictions around human-wildlife conflict.

Chapter 7 gives a useful overview and synthesis of disease interactions in the Serengeti. The various zoonoses and multispecies host reservoirs of pathogens are seen primarily in terms of diseases being introduced into the Serengeti from the surrounding human (tuberculosis) and domestic animal populations (rabies; canine distemper virus; nowextinct rinderpest). It is a moot point as to whether the multispecies nature of these diseases acts to exacerbate or damp down transmission. Intriguingly, disease among top predators may allow higher infectious disease transmission among prey populations, with ultimately adverse effects. Chapter 8 looks at food webs and models the implications of change. To manage the complexities involved, the author focuses on key 
components: two top predators (lion, hyena), two major herbivore species (wildebeest, buffalo) and two components of the grasslands (long and short grass associations). Interestingly, it suggests that the eruption of the wildebeest population, despite the positive effects on the extent and rate of grassland production, may be driving a long-term decline of other grazers such as Thompson's gazelle and buffalo.

Chapters 9 through 13 continue the modelling theme with a variety of approaches focusing on different components of the system. Chapter 9 looks at the spatial dynamics and coexistence of Serengeti grazers. Chapter 10 models the hunting behaviour of the peoples bordering the western edge of the Serengeti (Kuria, Ikoma, Sukuma). Using the same household decision-making model as in chapter 10, Chapter 11 begins to convey something of the western Serengeti peoples, their land use, livelihoods and interplay with the Serengeti National Park, estimating that people gain one-third of their income from hunting and selling bushmeat and one-third of households lose $25 \%$ of their crops to wildlife damage. Chapter 12 shifts focus to the broader system: the implications of human population growth and of anti-poaching enforcement on the one hand, and on the other, of wildlife management areas [WMAs] intended to foster a flow of economic benefits from conservation and tourism to local people. Chapter 13 contributes an analysis of the economics of land use decisions around the Mara. The Mara is fast becoming one of the more intensively studied areas from the viewpoint of economic returns to different land use choices, especially wildlife-based tourism options, but even so, studies can barely keep pace with the rate at which land tenure arrangements and tourism enterprises are evolving. Interestingly, since this volume appeared, the development of conservancies has in fact moved the state of play in the direction advocated by the authors. Chapter 14 gives a broad-brush synthesis of changes in the Serengeti Mara ecosystem through time, interpreting these largely in terms of Holling's (1973) theoretical frameworks of resilience; slow and fast variables, along with ideas around ideal free distribution, emergent properties of stable equilibrium and limit cycles, and gradual and sudden shifts between multiple stable states. Chapter 15 attempts to disentangle the murky dealings of tourism income and conservation expenditure for Serengeti and Ngorongoro. Sinclair's peroration in chapter 16 considers the roles of fortress and community conservation and of protected areas, with a call for zoning, enforcement and better benefits for communities.

Given the breadth and ambition of this book and the many exciting departures it presents in terms of modelling different aspects of the whole, it seems carping to query the extent to which this collection of papers really tackles human impacts on - and roles in creating - the Serengeti ecosystem. While drawing heavily on Ehret's (2002) inspiring grand canvas of the emergence and spread of different cultures and linguistic traditions and Iliffe's (1979) authoritative broad history, chapter 4 does little to engage with local work immediately in and around the Serengeti and across neighbouring Maasai areas whether by historians (Waller 1988; Waller and Lamprey 1990), oral histories and anthropological work (Goldman 2003, 2009; McCabe 2002, 2003), colonial historical sources (e.g. St John Grant 1954 as cited by Pearsall 1957) or to keep up-to-date with archaeological work. As a result, the chapter is misleading in parts. It attributes the arrival of cattle in East Africa to an early introduction of the zebu Bos indicus (refuted by Marshall 2000). It lacks awareness of the way burning is managed by pastoralist and other customary users around the world (cf. work by Laris 2002; Bird et al. 2005) with 
the commonly observed use of controlled burning, firebreaks, patch burning and early dry-season burns to produce a mosaic-grazing resource and, importantly, to avoid damaging, uncontrolled hot fires. Classification of land use choices in chapter 4 does not do justice to the ways pastoralist individuals, households and communities have historically shifted between herding, farming, gathering, hunting and (increasingly) wage earning from off-land work, from the colonial days of working as mercenaries for British pacification raids, when they were paid in cattle, to the present situation where off-farm wages make up the second most significant source of household income (after livestock) for most rural Maasai. This poor awareness of pastoralist practices in and around the Serengeti surfaces elsewhere: in chapter 2, the Maasai are characterised as not using fencing, where St John Grant in 1954 as cited by Pearsall (1957) clearly recorded the preeviction Serengeti Maasai making extensive use of fences to exclude wildebeest from key short grass plains grazing and water resources; in the present day, fencing is a major issue in and around other Maasai areas (Kitengela and the Mara). Throughout the book, the 1960s' eruption of the wildebeest is attributed solely from the release of rinderpest, but the eviction of a thousand Maasai and tens of thousands or more livestock from use of the short grass plains, along with the cessation of pastoralist practices of fencing off access to key grazing and water resources, is temporally coincident with and arguably likely to have played a part in triggering the eruption of the wild ungulates. Similarly, the 1960s' increase in hot fires and subsequent impacts on vegetation succession is nowhere linked even in part to eviction-related loss of pastoralists' early dry-season burning and of their herds' grazing pressure. These changes would have contributed to the accumulations of dry-season fuel, making the whole system much more subject to hot dry-season fires - as observed wherever indigenous fire management has been curtailed around the world (West African savanna states, USA, Australia). Chapter 5 is unable to evaluate pastoralists as historical agents of present day heterogeneity in the landscape, despite their known role in creating key hotspots in related and neighbouring systems. Though chapters 8 and 9 suggest that the dominance of wildebeest may drive long-term decline and loss of other grazing species, competition between cattle and wildebeest and removal of wildebeest through illegal hunting are nowhere considered as possible agents maintaining diversity.

Chapter 6 is rightly proud of the contribution that, for example, rabies vaccine interventions have made to human and domestic animal health around the Serengeti. However, there is a dangerous lack of any sense of incongruity that human and domestic animal public health interventions occur only as a downstream effect of wildlife concerns. Conservation ecologists should be aware of the way this may trigger an adverse rebound. The refusal of polio vaccine in Nigeria and the recurrent epidemics that ensued were in part driven by the people's resentment at the resources poured into what was seen locally as a lesser health issue while the people's major and pressing primary health care needs were going unmet and (in the case of Nigeria) big killers like measles left unaddressed. 'One Health' (simultaneous and coordinated provision of health measures for human and animal populations through shared systems) offers positive prospects, but it works best where horizontal primary health care systems are built up alongside any vertical, top-down, single disease-focused interventions.

It is not straightforward to strike the balance between the primary interest in ecosystem ecology and ecologists' emerging interest in social, economic and political context 
and drivers. It is not clear whether this focus on the natural resource base underlies the way the people's strategies appear exclusively natural resource-based (farm, herd, hunt), as do their possible responses to change, as explored in chapters 11 and 12 . Off-farm work, rural-urban links and urban migrant remittances do not appear among the livelihood choices and income streams presented though they would normally be salient among even the most remote of rural Tanzanian communities. Though chapter 12 addresses policies and concepts of community-based conservation, there is a rather limited engagement with the widespread issues around governance, financial accountability and elite capture associated with WMAs and other such interventions. Despite the expression of interest in the introduction and clear awareness of costs, as well as benefits of conservation to local communities, there is also a limited engagement with the literature around the Integrated Conservation and Development Projects and community-based conservation.

There is a diplomatic reticence or even silence around both the state capture (by 2007 ministerial decree) of supposedly community revenues from WMAs and about the spate of state-mediated land grabbing around the Serengeti by foreign investors (US financier Tudor Jones in western Serengeti; Ortello Business Company Arab hunting concession in Loliondo adjacent to and continuous with eastern Serengeti). The implications of this process have been analysed elsewhere by, for example, Igoe and Brockington (1999) and more generally by Zoomers (2010). There is an even louder diplomatic reticence about the income and expenditure figures for the Serengeti and Ngorongoro Conservation Area [NCA]. Without going into detail, the supposed expenditure of around USD 0.5 million per year on community development in NCA is an interesting claim given that these 40,000 people remain among the poorest in Tanzania (and in the world) in terms of assets, income, nutritional status and provision of education, health and infrastructure. The loss from one year to the next of $90 \%$ of this reported level of community support is not analysed in any depth. It is an open secret that a large part of NCA income from tourism is in fact diverted in unaccountable ways to bankrolling the ruling Chama Cha Mapinduzi party and that the official figures are dubious at best. The book could convey clearer doubts on reported figures known to be so extraordinarily vulnerable to corruption and lack of transparency.

More broadly, this book shows little awareness of the importance of land and its expropriation by state and/or investors (including conservation agencies) as an issue both for poverty in rural Tanzania and for stoking political anger and resentment against conservation (cf. McCabe 2002, 2003; Goldman 2003, 2009; Sachedina 2008 and others for the neighbouring area of Simanjiro). The issue of human/wildlife conflict emerges in several chapters, but nowhere the understanding that this may often be a misleading construct and that, for example, predation losses to livestock are generally very much lower than the expressed anger against wildlife would suggest. The mismatch has been shown not only in Africa, but also in the USA and Europe, to have more to do with political resentment at the imposition of controls by outsiders than it has to do with actual losses. It is increasingly recognised that a very large part of 'human wildlife conflict' is rather a human to human conflict between different interest groups with polarised views as to who should be able to dictate the use of land and wildlife and with generally very different levels of political clout and economic prosperity (see e.g. work by Manfredo et 
al. 2009 for the USA). This has implications for many of the book's assumptions and predictions about increased human/wildlife conflict and attitudes to wildlife.

Individually, these may seem minor issues. They do not detract from the very real scientific achievements of the work, nor from the major effort it has taken for a group of dedicated ecologists to begin to take on board the way this much-loved ecosystem has a human history and a human context that has driven its past and present forms and will dictate its future. However, in a book subtitled Human impacts on ecosystem dynamics, the history, lives and practices of people linked with using and shaping this ecosystem over the millennia arguably deserve even more informed and nuanced treatment. When that is achieved, the rewards to ecological science will come through more robust conceptual models that are better able to address the management issues and ever betterconceived research questions leading to an ever more incisive understanding. This volume reports on an exciting project that is a work in progress: I am already looking forward to Serengeti IV.

Competing interests

The author declares that she has no competing interests.

Received: 9 October 2011 Accepted: 21 October 2011 Published: 21 October 2011

References

Bird, DW, R Bliege Bird, and CH Parker. 2005. Aboriginal burning regimes and hunting strategies in Australia's western desert. Human Ecology 33:443-464. doi:10.1007/s10745-005-5155-0.

Ehret, C. 2002. The civilizations of Africa: A history to 1800. Charlottesville, VA: University of Virginia Press.

Goldman, Mara. 2003. Partitioned nature, privileged knowledge: Community based conservation in Tanzania. Development and Change 34(5):833-862. doi:10.1111/j.1467-7660.2003.00331.x.

Goldman, Mara. 2009. Constructing connectivity: Conservation corridors and conservation politics in East African rangelands. Annals of the Association of American Geographer 99(2):335-359. doi:10.1080/00045600802708325.

Holling, CS. 1973. Resilience and stability in ecological systems. Annual Review of Ecology and Systematics 4:1-23. doi:10.1146/annurev.es.04.110173.000245.

Igoe, J, and D Brockington. 1999. Pastoral land tenure and community conservation: A case study from north-east Tanzania. Pastoral Land Tenure Series 11. London: International Institute for Environment and Development.

lliffe, J. 1979. Modern history of Tanganyika. African Studies Series 25. Cambridge: Cambridge University Press.

Iliffe, J. 1987. The African poor: A history. Cambridge: Cambridge University Press.

Laris, P. 2002. Burning the seasonal mosaic: Preventative burning strategies in the wooded savanna of southern Mali. Human Ecology 30(2):155-186. doi:10.1023/A:1015685529180.

Manfredo, M, T Teel, and K Henry. 2009. Linking society and environment: A multilevel model of shifting wildlife value orientations in the western United States. Social Science Quarterly 90(2):407-427. doi:10.1111/j.1540-6237.2009.00624.x.

Marshall, F. 2000. The origins and spread of domestic animals in East Africa. In The origins and development of African livestock: Archaeology, genetics, linguistics and ethnography, eds. Blench R, Macdonald K, 191-121. London: University College London Press.

McCabe, JT. 2002. Conservation with a human face? Lessons from 40 years of combining conservation and development in the Ngorongoro Conservation Area, Tanzania. In Displacement, forced settlement and conservation, ed. Chatty D, 61-76. Oxford: Berghahn Books.

McCabe, JT. 2003. Disequilibrial ecosystems and livelihood diversification among the Maasai of northern Tanzania: Implications for conservation policy in eastern Africa. Nomadic Peoples 7(1):74-91. doi:10.3167/082279403782088921.

Pearsall, WH. 1957. Report on an ecological survey of the Serengeti National Park, Tanganyika. Fauna Preservation Society, London 64 pp. Reprinted in Oryx 4:71-136.

Sachedina, H. 2008. Wildlife is our oil: Conservation, livelihoods and NGOs in the Tarangire ecosystem, Tanzania. Unpublished PhD thesis, Oxford University.

Sinclair, A, and M Norton-Griffiths. 1979. Serengeti: Dynamics of an ecosystem. Chicago: Chicago University Press.

Sinclair, A, and P Arcese. 1995. Serengeti II: Dynamics, management and conservation. Chicago: Chicago University Press.

Waller, R. 1988. Emutai: Crisis and response in Maasailand, 1884-1904. In The ecology of survival: Case studies from north-east African history, eds. Johnson D, Anderson D, 72-112. London: University of Oxford. Inter-faculty Committee on African Studies.

Waller, R, and R Lamprey. 1990. The Loita-Mara area in historical times: Patterns of subsistence, settlement and ecological change. In Early pastoralists of south-western Kenya, ed. Robertshaw P, 16-35. Nairobi: Publisher.

Zoomers, A. 2010. Globalisation and the formalisation of space: Seven processes driving the current global land grab. Journal of Peasant Studies 37(2):429-447.

doi:10.1186/2041-7136-1-22

Cite this article as: Homewood: Review of Serengeti III: human impacts on ecosystem dynamics edited by ARE Sinclair, Craig Packer, Simon Mduma and John M Fryxell. Pastoralism: Research, Policy and Practice 2011 1:22. 